\title{
A repetitive probe for FISH analysis of bovine interphase nuclei
}

\author{
Wafa Slimane ${ }^{a, b}$, Daniel VAIMAN ${ }^{c}$, Sophie GODARD ${ }^{c}$, \\ Anne VAIMAN ${ }^{c}$, Edmond CRIBIU ${ }^{c}$, Jean-Paul RENARD ${ }^{a *}$ \\ ${ }^{a}$ Unité biologie du développement, Institut national de la recherche agronomique, \\ 78352 Jouy-en-Josas Cedex, France \\ b Services techniques de l'Union national des coopératives d'élevage et \\ d'insémination artificielle, 13, rue Jouët, BP 65, 94703 Maisons-Alfort, France \\ ${ }^{\mathrm{c}}$ Génétique biochimique et cytogénétique, Institut national de la recherche \\ agronomique, 78352 Jouy-en-Josas Cedex France
}

(Received 22 June 1999; accepted 20 December 1999)

\begin{abstract}
The purpose of this study was to generate repetitive DNA sequence probes for the analysis of interphase nuclei by fluorescent in situ hybridisation (FISH). Such probes are useful for the diagnosis of chromosomal abnormalities in bovine preimplanted embryos. Of the seven probes (E1A, E4A, Ba, H1A, W18, W22, W5) that were generated and partially sequenced, five corresponded to previously described Bos taurus repetitive DNA (E1A, E4A, Ba, W18, W5), one probe (W22) shared no homology with other DNA sequences and one (H1A) displayed a significant homology with Rattus norvegicus mRNA for secretin receptor transmembrane domain 3. Fluorescent in situ hybridisation was performed on metaphase bovine fibroblast cells and showed that five of the seven probes hybridised most centromeres (E1A, E4A, Ba, W18, W22), one labelled the arms of all chromosomes (W5) and the H1A probe was specific to three chromosomes (ch14, ch20, and ch25). Moreover, FISH with H1A resulted in interpretable signals on interphase nuclei in $88 \%$ of the cases, while the other probes yielded only dispersed overlapping signals.
\end{abstract}

satellite DNA / FISH / bovine / centromere

Résumé - Génération d'une sonde bovine à séquences répétées pour l'analyse en FISH des noyaux bovins en interphase. L'objectif de cette étude est d'isoler des sondes nucléiques bovines spécifiques d'un faible nombre de chromosomes permettant une analyse par hybridation in situ fluorescente (FISH) des noyaux en interphase. De telles sondes présentent un outil précieux pour l'étude d'anomalies chromosomiques d'embryons chez les bovins. Sept sondes ont été générées (E1A, E4A, Ba, H1A, W18, W22, W5) et partiellement séquencées : cinq d'entre elles correspondent à des séquences répétées d'ADN génomique bovin déjà décrites (E1A, E4A, Ba, W18, W5),

\footnotetext{
* Correspondence and reprints

E-mail: renard@biotec.jouy.inra.fr
} 
la sonde W22 ne présente à ce jour aucune homologie avec les séquences connues dans "Genbank" et la dernière, H1A (3,5 kb isolée après digestion par l'enzyme HindIII) présente une homologie significative sur 158 paires de base avec l'ARNm codant pour le $3^{\mathrm{e}}$ domaine transmembranaire du récepteur de la secrétine de rat (Rattus norvegicus). L'hybridation in situ fluorescente sur des fibroblastes bovins en métaphase a montré que cinq sondes (E1A, E4A, Ba, W18, W22) hybrident la plupart des centromères, que la sonde W5 marque les bras de tous les chromosomes, et que la sonde H1A est spécifique de trois chromosomes bovins (ch14, ch20 et ch25). De plus, sur noyaux interphasiques, l'utilisation de H1A a permis d'obtenir des signaux interprétables dans $88 \%$ des cas, contrairement aux autres sondes qui donnent des signaux superposés difficiles à interpréter.

ADN satellite / FISH / bovin / centromère

\section{INTRODUCTION}

Highly repetitive DNA represents a large fraction of most eukaryotic genomes. In mammals, these DNA components are either dispersed throughout the genome or arranged in tandem in large blocks known as satellite DNA $[4,31]$, which often localise to pericentromeric areas. Probes containing such sequences are considered as powerful tools for detecting numerical chromosome abnormalities in eukaryotic cells [14]. After fluorescent in situ hybridisation (FISH), they display distinct bright signals in metaphase as well as interphase cells $[11,25]$. These probes are now routinely used in human clinical cytogenetics for various applications such as studying cellular disorders associated with tumoral cells $[1,24]$, or genetic aberrations in tumours by analysing a single cell suspension isolated from solid cancer. Thus, this method avoids cell culture that may lead to selective growth of cells with the highest mitotic index [26].

FISH using repetitive probes has also been successfully applied for prenatal diagnosis by analysing uncultured amniotic fluid samples as well as for human preimplantation embryo diagnosis $[15,16,23]$. Recently, the use of repetitive probes enabled preconception diagnosis by FISH analysis of both human oocytes $[23,35]$ and spermatozoa $[25,32]$.

In the bovine species, very few repetitive DNA probes are available [33]. This is partly due to the fact that, in animal research programmes, FISH is mainly used for physical genome mapping which involves unique sequence probes to localise genes or genetic markers on metaphase plates [5, 30]. However, in interphase nuclei, FISH using such probes does not allow accurate screening, as signals are usually very weak and may be confused with the background.

With the recent advances in biotechnology associated with embryo transfer in cattle, the study of genetic disorders in preimplantation embryos is becoming highly relevant. Until now, chromosomal abnormalities in bovine embryos have mainly been studied by karyotyping. Whole embryos incubated overnight in colchicine $[18,20]$, have yielded very variable estimates of the aberrations. For example, the incidence of chromosomal abnormalities in 2-cell bovine embryos has been estimated at $12 \%$ by Iwasaki and Nakahara [17] and at $36 \%$ by Iwasaki et al. [18]. In the same way, results on karyotypes at the blastocyst stage differ according to studies. The main category observed is mixoploidy, which varies between $44 \%$ [18] and 99\% [9]. This variability is mainly due to the fact that only a minor proportion of embryonic cells can be analysed. Our study aims 
to generate repetitive bovine DNA probes for the screening of chromosomal abnormalities. In this work, we isolated and cloned seven repetitive probes, one of which hybridised to a limited number of chromosomes. This probe represents a promising tool for characterising the genetic status of interphase nuclei, particularly for diagnosing embryos deriving from transgenesis or cloning biotechnologies.

\section{MATERIALS AND METHODS}

\subsection{Probes generation}

Bovine genomic DNA was prepared according to Jeanpierre [19], and was digested in six independent reactions by one of six different restriction endonucleases (BamH1,SacI, StuI, EcoRI, EcoRV and HindIII). After digestion, restricted genomic DNA was run on 1\% agarose gel in 1XTBE buffer overnight at $60 \mathrm{~V}$ and stained with ethidium bromide. Prominent bands corresponding to repetitive DNA elements were cut out from the gel, extracted, and purified by the deep freeze / phenol technique [34]. Purified bands were ligated into pGEM4Z (Promega) (pre-disgested with restriction enzymes yielding compatible ends and dephosphorylated) in $20 \mu \mathrm{L}$ total volume at $16{ }^{\circ} \mathrm{C}$ overnight. One $\mu \mathrm{L}$ of ligation was electroporated into $20 \mu \mathrm{L}$ home-made DH10B electro competent cells grown in $3 \mathrm{~mL}$ of LB.

White colonies which likely corresponded to positive transformants containing the ligated band were selected after plating the transformation product on LB plates with Ampicilline $\left(100 \mu \mathrm{g} \cdot \mathrm{mL}^{-1}\right)$. DNA was extracted from the positive colonies, digested with the same enzyme used for plasmid digestion, and electrophoresed on a 1\% agarose gel to check that the insert was cloned. This was done by ascertaining that the molecular weight of the band was the same as that of the DNA fragment in the ligation product.

Roughly 500 bp of each probe were sequenced from one strand using a universal primer vector. The DNA sequences obtained were compared with Genbank/EMBL using the Blast program.

\subsection{Probes labelling}

Probes were labelled with biotin 16-dUTP (Boehringer Mannheim, Germany) using a nick translation kit (GIBCO - BRL). Usually, $200 \mathrm{ng}$ of DNA were labelled in a $50 \mu \mathrm{L}$ mixture containing (1) $0.2 \mathrm{mM}$ each of dATP, dCTP, dGTP, (2) $0.35 \mathrm{mM}$ biotin 16-dUTP, (3) 2.5 U DNA polymerase I, (4) $2 \mathrm{mU}$ DNAse I.

Labelled DNA samples were ethanol precipitated in the presence of sonicated salmon sperm DNA $(100 \mu \mathrm{g})$. Precipitates were dissolved in $20 \mu \mathrm{L}$ of hybridisation mixture $\{60 \%$ formamide (Sigma) in SSP (Saline Sodium Phosphate) and $10 \%$ dextran sulfate (Pharmacia) $\}$ at $37^{\circ} \mathrm{C}$, approximately $30 \mathrm{~min}$ prior to denaturation (6 min at boiling temperature) and chilled rapidly on ice.

\subsection{In situ hybridisation (ISH)}

In situ hybridisation was performed on bovine fibroblasts from a cell line available in the laboratory (59 XX, t4.10). Subsequently, a normal 60XX cell 
line was used to validate the results. After BrdU incorporation during the late S phase, air-dried chromosomal preparations were obtained using standard procedures [7]. Protocols used for FISH were as previously described in Bahri-Darwich et al. [2]. Chromosomal DNA was counterstained and R-banded by the direct fluorescent technique described by Lemieux et al. [21]. The slides were screened with a Leica fluorescence microscope and photomicrographs were taken with a Fujichrome 400 Asa colour slide film.

Chromosome identification was performed according to the Texas nomenclature [27]. FISH experiments were carried out with the seven probes and the specificity of each probe was determined on both metaphase and interphase bovine fibroblasts. Each probe was used in five independent experiments, each of which involved scoring 50 interphase and 10 metaphase cells from the 59 $\mathrm{XX}, \mathrm{t} 4.10$ cell line. In addition, each probe was subsequently hybridised on the 60XX cell line.

\section{RESULTS}

After digestion of genomic DNA samples by six different enzymes, 11 prominent bands ranging from 0.8 to $3.5 \mathrm{~kb}$ were clearly identified. Seven out of the 11 bands were cloned. DNA sequence analysis revealed $90-95 \%$ identity with Bos taurus repetitive sequences (satellite or SINE) for five of the seven probes. One probe (AF124263) revealed no homology with previously described DNA sequences, and another one (AF118556) derived from the 3.5 kb HindIII fragment, displayed $90 \%$ identity with a Rattus norvegicus secretin receptor transmembrane domain 3 from which $158 \mathrm{bp}$ out of 500 were sequenced (Tab. I).

After FISH, all these probes gave clear fluorescent signals in fibroblast metaphases derived from the $59 \mathrm{XX}, \mathrm{t} 4.10$ as well as the 60XX cell lines. Each one consisted of a set of small clustered spots producing a bright distinct signal. The W5 probe, which corresponded to the SINE sequence, hybridised to all chromosomes from each metaphase, and painted the entire arms of chromosomes except for the centromeres (Fig. 1a); five other probes hybridised to a large number of centromeres (Fig. 1b), and appeared to be specific for about 25 of the 30 pairs of chromosomes. The last probe (H1A) hybridised to subcentromeric regions of only three chromosomes and provided six strong signals which where clearly identified on all the metaphases analysed (Fig. 1c and $1 \mathrm{~d})$.

FISH in interphase fibroblast nuclei showed that all probes except H1A yielded overlapping signals which were widely dispersed through the optical section of the nuclei, making an accurate count impossible (Fig. 2a). In contrast, six fluorescent signals (Fig. 2b) could be clearly counted in $70 \%(175 / 250)$ of the nuclei when hybridised with the H1A clone. Carefull screening of labelled nuclei made it possible to identify $10 \%(25 / 250)$ nuclei with three spots (haploid) and $8 \%(20 / 250)$ nuclei with 12 signals (hyperploid). Some cells $(12 \% ; 30 / 250)$ could not be scored because of intermingling signals. 
Table I. Probe sequence analysis.

\begin{tabular}{lll}
\hline Probes & Homologous to & Localisation \\
\hline E1A (EcoRI) & $\begin{array}{l}\text { Bovine 1.715 satellite } \\
(\text { embV00124) }\end{array}$ & Most centromeres \\
E4A (EcoRI) & $\begin{array}{l}\text { Bos taurus microsatellite } \\
\text { DVEPCO46 (gb/U95979) }\end{array}$ & Most centromeres \\
Ba (BamH1) & $\begin{array}{l}\text { Bovine genomic fragment for } \\
\text { 1.709 satellite DNA } \\
\text { (emb/X00979) }\end{array}$ & Most centromeres \\
H1A (HindIII) & $\begin{array}{l}\text { Rattus norvegicus mRNA for } \\
\text { secretin receptor } \\
(\text { emb/X59132) }\end{array}$ & $\begin{array}{l}\text { Subcentromeric regions of } \\
\text { chromosomes 14, 20, 25 }\end{array}$ \\
W18 (SacI) & $\begin{array}{l}\text { Bovine satellite DNA } \\
\text { fragment(emb/VOO122) }\end{array}$ & Most centromeres \\
W22 (EcoRV $)$ & $\begin{array}{l}\text { No homology } \\
\text { Bos taurus DNA for SINE }\end{array}$ & All chromatids \\
& $\begin{array}{l}\text { sequence Bov-1D } \\
\text { (emb/X64126) }\end{array}$ & \\
\hline
\end{tabular}

* Figures in brackets indicate accession numbers with EMBL/GenBank data base.

\section{DISCUSSION}

In genomic cytogenetic mapping studies, the objective is to locate a given genomic sequence in a specific chromosomal region; therefore, the most suitable probes are those derived from a unique sequence [30]. Conversely, it has been demonstrated that probes containing centromeric repetitive sequences are the most adequate for detecting numerical aberrations in interphase nuclei $[8,10$, $28,37]$. In humans, repetitive sequence probes specific for each chromosome are now commercially available [14], whereas bovine chromosome specific probes come mainly from cosmid and YAC/BAC libraries and are only recently available in a few laboratories [5, 12, 13, 22, 30].

The approach used in this study made it possible to isolate a probe (H1A) suitable for analysing interphase nuclei. Using this probe, abnormal plö̈dies were detected in interphase nuclei where $8 \%$ and $10 \%$ of cells yielded more or less than six signals, respectively. Since no abnormal numbers were detected in metaphases, these discrepancies could stem from the fact that we scored only complete metaphases, incomplete ones being discarded to avoid confusion with a hypotonic treatment artefact. The abnormal numbers observed on interphase nuclei could correspond to hyper- and hypoploid nuclei respectively, and be attributed to the cell line used [6]. However, a hybridisation artefact which may be due to superimposition of signals when two labelled chromosomes lie immediately adjacent or on top of each other, should not be disregarded [11]. 

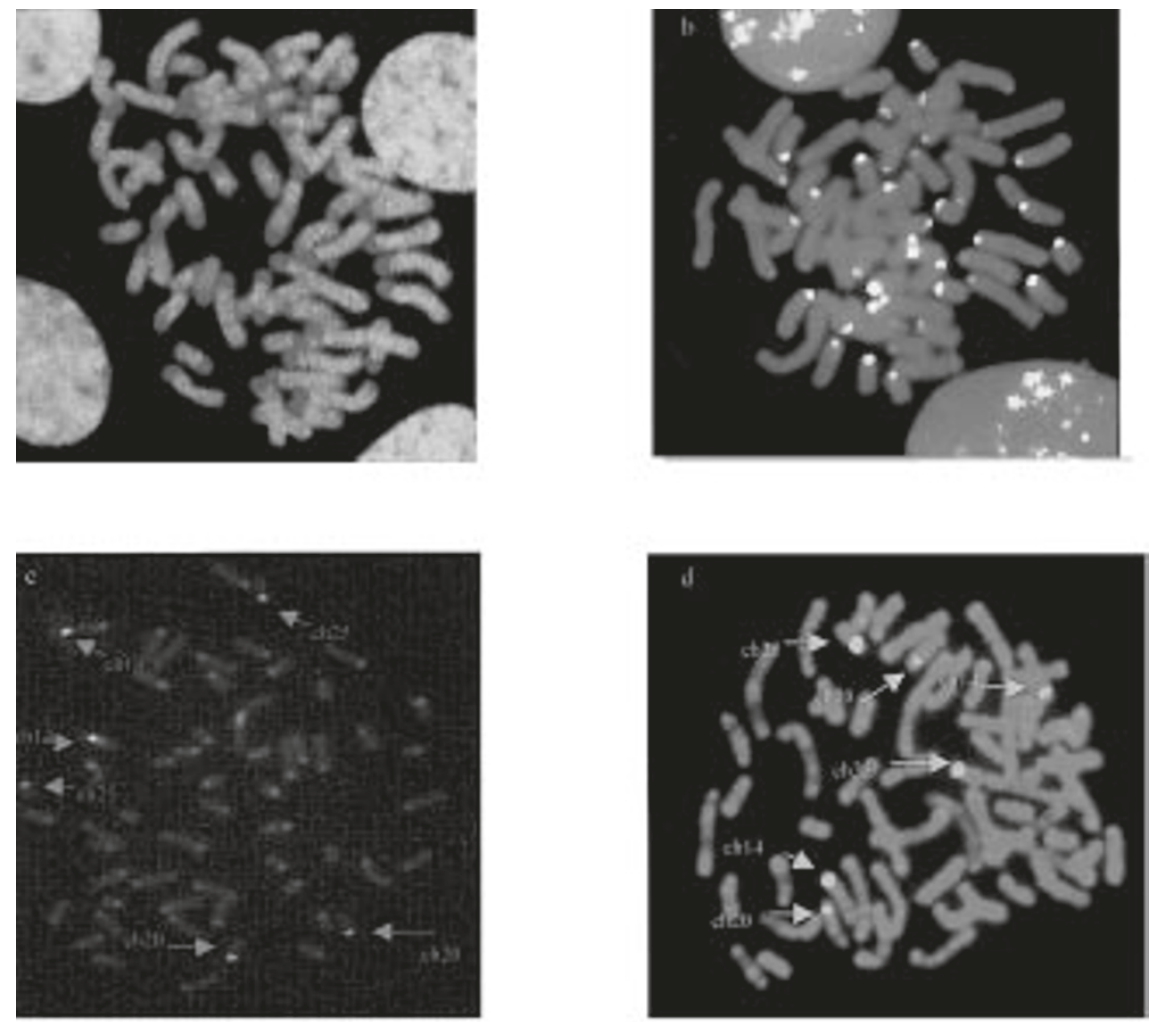

Figure 1. Signals obtained following hybridisation on metaphase cells. a. A 59XXt4.10 cell line hybridised with the W5 probe.

b. A 59XXt4.10 cell line hybridised with the E1A probe.

c. A 59XXt4.10 cell line hybridised with the H1A probe.

d. A normal 60XX cell line hybridised with the H1A probe.

Apart from these limitations, the H1A probe offers the advantage of hybridising to three chromosome pairs simultaneously. It thus provides an accurate assessment of aneuploidies in interphase nuclei, since it discriminates between monosomy for a single chromosome and complete haploidy.

In conclusion, our work has enabled us to isolate a probe specific to a limited number of chromosomes. Increasing the number of restriction enzymes for a more complete digestion of genomic DNA would probably generate a panel of new probes which could be used for routine detection of numerical chromosome abnormalities in cattle cells. Alternatively, the isolation of sequences specific to chromosome fragments or whole chromosome painting probes by microdissection might be the method of choice to generate a complete set of chromosome specific probes. The feasibility of such an approach is widely reported in humans $[3,29,36]$. These probes would constitute promising tools for analysing the chromosomes of embryonic cells which are now widely used in biotechnology. 

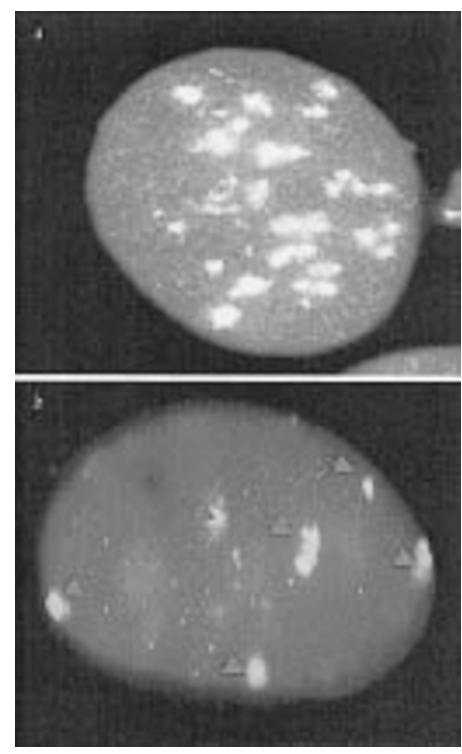

Figure 2. Signals obtained following hybridisation on interphase nuclei. a. A 59XXt4.10 cell line hybridised with the Ba probe.

b. A 59XXt4.10 cell line hybridised with the H1A probe.

\section{ACKNOWLEDGEMENTS}

We thank Dr H. Hayes and Dr I. Hue for helpful discussions. This work was partly supported by a grant from the European contract CT950190. W. Slimane is the recipient of a fellowship from INRA. We also thank A.M. Wall for revising the manuscript.

\section{REFERENCES}

[1] Afify A., Mark H.F., Trisomy 8 in embryonal rhabdomyosarcoma detected by FISH, Cancer Genet. Cytogenet. 108 (1999) 127-132.

[2] Bahri-Darwich I., Vaiman D., Olsaker I., Oustry A., Cribiu E.P., Assignment of bovine synteny groups U27 and U8 to R-banded chromosome 12 and 27, respectively, Hereditas 120 (1994) 261-265.

[3] Bolzer A., Craig J.M., Cremer T., Speicher M.R., A complete set of repeatdepleted, PCR-amplifiable, human chromosome-specific painting probes, Cytogenet. Cell Genet. 84 (1999) 233-240.

[4] Brutlag D.L., Molecular arrangement and evolution of heterochromatic DNA, Annu. Rev. Genet. 14 (1980) 121-144.

[5] Cai L., Taylor J. F., Wing R.A., Gallagher D.S., Woo S.S., Davis S.K., Construction and characterization of a bovine bacterial artifical chromosome library, Genomics 29 (1995) 413-425.

[6] Cribiu E.P., Popescu C.P., L'aneuploïdie et la polyploïdie chez les bovins dans les cultures de cellules bovines, Ann. Génét. Sél. Anim. 9 (1977) 275-282. 
[7] Cribiu E.P., Matejka M., Darre R., Durand V., Berland H.M., Bouvet A., Identification of chromosomes involved in a Robertsonian translocation in cattle, Genet. Sel. Evol. 21 (1989) 555-560.

[8] de Sario A., Vagnarelli P., De Carli L., Aneuploidy assay on diethylstilbestrol by means of in situ hybridization of radioactive and biotinylated DNA probes on interphase nuclei, Mutat. Res. 243 (1990) 249-253.

[9] Dorland M., Duijndam W.A.L., Kruip Th.A.M., Donk J.A. van der, Cytogenetic analysis of day-7 bovine embryos by cytophotometric DNA measurements, J. Reprod. Fertil. 99 (1993) 681-688.

[10] Eastmond DA., Pinkel D., Detection of aneuploidy and aneuploidy-inducing agents in human lymphocytes using fluorescence in situ hybridization with chromosome specific DNA probes, Mutat. Res. 234 (1990) 303-318.

[11] Eastmond D.A., Rupa D.S., Hasegawa L.S., Detection of hyperdiploidy and chromosome breakage in interphase human lymphocytes following exposure to the benzene metabolite hydroquinone using multicolor fluorescence in situ hybridization with DNA probes, Mutat. Res. 322 (1994) 9-20.

[12] Eggen A., Solinas T.S., Fries R.A., Cosmid specific for sequences encoding a microtubule associated protein, MAPIB, contains a polymorphic microsatellite and maps to bovine chromosome 20q14, J. Hered. 89 (1998) 359-363.

[13] Godard S., Schibler L., Oustry A., Cribiu E.P., Guérin G., Construction of a horse BAC library and cytogenetical assignment of 20 type I and type II markers, Mamm. Genome 9 (1998) 637-638.

[14] Gole L.A., Bongso A., Fluorescent in-situ hybridization - Some of its applications in clinical cytogenetics, Singapore Med. J. 38 (1997) 497-503.

[15] Griffin D.K., Handyside A.H., Harper J.C., Wilton L.J., Atkinson G., Soussi I., Wells D., Kontogianni E., Tarin J., Geber S., Asangla A.O., Winston R.M.L., Delhanty J.D.A., Clinical experience with preimplantation diagnosis of sex by dual FISH, J. Assist. Reprod. Genet. 11 (1994) 132-142.

[16] Handyside A.M., Delhanty J.D.A., Cleavage stage biopsy of human embryos and diagnosis of X-linked recessive disease, in: Edwards R.G. (Ed.), Preimplantation Diagnosis of Human Genetic Disease, University Press, Cambridge, 1993, pp.239-270.

[17] Iwasaki S., Nakahara T., Incidence of embryos with chromosomal anomalies in the inner cell mass among bovine blastocysts fertilized in vitro, Theriogenology 34 (1990) 83-690.

[18] Iwasaki S., Hamano S., Kuwayama M., Yamashita M., Ushijima H., Nagaoka S., Nakahara T., Developmental changes in the incidence of chromosome abnormalities of bovine embryos fertilized in vitro, J. Exp. Zool. 216 (1992) 79-85.

[19] Jeanpierre M., A rapid method for the purification of DNA from blood, Nucleic Acids Res. 15 (1987) 9611.

[20] Kawarsky S.J., Basrur P.K., Stubbings R.B., Hansen P.J., King A.W., Chromosomal abnormalities in bovine embryos and their influence on development, Biol. Reprod. 54 (1996) 53-59.

[21] Lemieux N., Dutrillaux B., Viegas-Pequignot E., A simple method for simultaneous R- or G-banding and fluorescence in situ hybridization of small single-copy genes, Cytogenet. Cell Genet. 59 (1992) 311-312.

[22] Libert F., Lefort A., Okimoto R., Womack J., Georges M., Construction of a bovine genomic library of large yeast artificial chromosome clones, Genomics 18 (1993) 270-276.

[23] Munné S., Khalid M., Sultan M., Heinz-Ulrich Weier M.D., Assessment of numeric abnormalities of X, Y, 18, and 16 chromosomes in preimplantation human embryos before transfer, Am. J. Obstet. Gynecol. 172 (1995) 1191-1201.

[24] Onodera N., Nakahata T., Tanaka H., Ito R., Honda T., Trisomy 6 in a childhood acute mixed lineage leukemia, Acta. Paediatr. Jpn. 40 (1998) 616-620. 
[25] Pellestor F., Quenesson I., Coignet L., Girardet A., Andréo B., Lefort G., Charlieu J.P., FISH and PRINS, a strategy for rapid chromosome screening: application to the assessment of aneuploidy in human sperm, Cytogenet. Cell Genet. 72 (1996) 34-36.

[26] Poddighe P.J., Moesker O., Smeets D., Awwad B.H., Ramaekers F.C.S., Interphase cytogenetics of hematological cancer: comparison of classical karyotyping and in situ hybridization using a panel of eleven chromosome specific DNA probes, Cancer Res. 51 (1991) 1959-1967.

[27] Popescu C.P., Long S., Riffs P., Womack J., Schmutz S., Fries R., Gallagher D.S., Standardization of cattle karyotype nomenclature: report of the committee for the standardization of the cattle karyotype, Cytogenet. Cell Genet. 74 (1996) 259-261.

[28] Raimondi E., Scariolo S., De Sario A., De Carli L., Aneuploidy assays on interphase nuclei by means of in situ hybridization with DNA probes, Mutagenesis 4 (1989) 165-169.

[29] Schermelleh L., Thalhammer S., Heckl W., Posl H., Cremer T., Schutze K., Cremer M., Laser microdissection and laser pressure catapulting for the generation of chromosome-specific paint probes, Biotechniques 27 (1999) 362-367.

[30] Schibler L., Vaiman D., Oustry A., Giraud-Delville C., Cribiu E.P., Comparative gene mapping: a fine-scale survey of chromosome rearrangements between ruminants and humans, Genome Res. 8 (1998) 901-915.

[31] Singer M., Highly repeated sequences in mammalian genomes, Int. Rev. Cytol. 76 (1982) 67-112.

[32] Spriggs E.L., Rademaker A.W., Martin R.H., Aneuploidy in human sperm: the use of multicolor FISH to test various theories of non-disjunction, Am. J. Hum. Genet. 55 (1996) 356-362.

[33] Solinas-Toldo S., Mezzelani A., Hawkins G.A., Bishop M.D., Olsaker I., Mackinlay A., Ferretti L., Fries R., Combined Q-banding and fluorescence in situ hybridization for the identification of bovine chromosome 1 to 7 , Cytogenet. Cell Genet. 69 (1995) 1-6.

[34] Vaiman D., Régulation par les interférons de la transcription des formes de poids moléculaires 40 et $46 \mathrm{Kda}$ de la 2'-5' oligo-A synthétase, Doctorat de Génétique humaine de l'Université Paris VII, 1991, 167 p..

[35] Verlinsky Y., Cieslak J., Freidine M., Luakhnentko V., Wolf G., Kovalinskaya L., White M., Lifchez A., Kaplan B., MoiseJ Valle J., Ginsberg N., Strom C., Kuliev A., Pregnancies following preconception diagnosis of common aneuploidies by FISH, Human Reprod. 10 (1995) 1923-1927.

[36] Weimer J., Kiechle M., Senger G., Wiedemann U., Ovens-Raeder A., Schuierer S., Kautza M., Siebert R., Arnold N., An easy and reliable procedure of microdissection technique for the analysis of chromosomal breakpoints and marker chromosomes, Chromosome Res. 7 (1999) 355-362.

[37] Zhao L., Khan Z., Hayes K.J., Glassman A.B., Interphase fluorescence in situ hybridization analysis: A study using centromeric probes 7, 8, and 12, Ann. Clin. Lab. Sci. 28 (1998) 51-56. 